\title{
POTENSI PENERAPAN SELF-LOCKING WALL PADA PEMANFAATAN LIMBAH SLUDGE DEINKING INDUSTRI KERTAS SEBAGAI BATAKO INTERLOK
}

\author{
Reza Bastari Imran Wattimena a , Aep Surachman a, Wachyudin Aziz a \\ ${ }^{\text {a }}$ Balai Besar Pulp dan Kertas \\ Jl. Raya Dayeuhkolot 132 Bandung 40258 Telp. (022) 5202980 Fax. (022) 5202871 \\ * e-mail : bbpk@bbpk.go.id \\ Diterima : 21 April 2011, Revisi akhir : 2 Juni 2011
}

\section{SELF-LOCKING WALL APPLICATION POTENTION ON PAPER INDUSTRY DEINKING SLUDGE USAGE AS INTERLOCK BRICKS}

\begin{abstract}
This research utilize the wastewater sludge into construction/building materials, i.e brick (brick concrete) as partition interlock system (self-locking wall). With the amount of deinking sludge ranged $3-4 \%$ of production capacity and moisture content reaches $60-80 \%$, providing an opportunity for the beneficiaries in the availability of cheap raw materials. This experiment using composition variation of cement : sand: sludge to determine optimum composition based on the physical test for several parameters such as compressive strength and Factor of Safety (FOS). Solidwork $2009^{\circledR}$ software is used to determined the shape and dimension that suitable to be applied at knock-down house. This program is also used to analyze the strength of self-locking wall products with different forms of locking to improve the strength and meets the minimum quality level of "Mutu Bata Beton Pasangan Dinding" (SNI 03-0349-1989), that is $21 \mathrm{~kg} / \mathrm{cm}^{2}$. It shows that interlock brick from deinked pulp and waste paper, compotition 1:8 with 50 \& 70\% sludge persentation give good result to be used as self-locking wall concept.
\end{abstract}

Key words : sludge, interlock brick, knock-down house, self-locking wall

\begin{abstract}
ABSTRAK
Penelitian ini memanfaatkan sludge industri kertas menjadi bahan bangunan batako (bata beton) sebagai partisi dengan pemasangan sistem interlock (self-locking wall). Jumlah sludge industri kertas berkisar 3-4 \% kapasitas produksi dengan kadar air 60-80\% memberikan peluang ketersediaan bahan baku yang murah. Percobaan menggunakan variasi komposisi semen : pasir : sludge untuk menentukan komposisi yang optimum atas dasar uji fisik beberapa parameter seperti kuat tekan dan Factor of Safety (FOS). Untuk merancang produk, dimanfaatkan perangkat lunak Solidworks ${ }^{\circledR} 2009$, sehingga didapatkan bentuk dan dimensi yang sesuai untuk diterapkan pada rumah knock down. Dengan perangkat lunak ini dapat diperoleh bentuk pengunci yang dapat membantu meningkatkan kekuatan produk self locking wall yang memenuhi persyaratan Mutu Bata Beton Pasangan Dinding (SNI 03-0349-1989) kelas IV sebesar $21 \mathrm{~kg} / \mathrm{cm}^{2}$. Hasil penelitian menunjukkan bahwa batako interlok menggunakan campuran bahan baku deinked pulp dan kertas bekas, komposisi $1: 8$ dengan persentase serat sebanyak 50\% \& 70\% memenuhi persyaratan untuk digunakan sebagai pengisi dinding/partisi sistem self-locking wall.
\end{abstract}

Kata kunci : limbah padat, batako interlok, knock-down, self-locking wall 


\section{PENDAHULUAN}

Meningkatnya industri khususnya industri kertas akan diikuti pula dengan meningkatnya jumlah limbah yang dihasilkan diantaranya dapat berupa limbah cair maupun limbah padat, sehingga resiko terhadap kerusakan lingkungan juga akan semakin bertambah. Salah satu upaya untuk mengantisipasinya adalah dengan cara mengolah kembali limbah tersebut menjadi barang yang bermanfaat. Limbah sludge dari industri kertas dalam Peraturan Pemerintah No.18 tahun 1999 dan perubahannya Peraturan Pemerintah No.85 tahun 1999 tentang Pengelolaan Limbah B3, tidak dicantumkan dalam daftar limbah kategori B3 dari sumber yang spesifik kecuali yang terkontaminasi dengan tinta (proses deinking). Namun demikian, tidak berarti limbah tersebut digolongkan sebagai limbah non B3. Pada PP RI No.18/1999 Jo. PP No.85/1999 tentang "Pengelolaan Limbah Bahan Berbahaya \& Beracun", menjelaskan bahwa setiap industri wajib melakukan pengelolaan limbahnya tanpa menggolongkan limbah apapun termasuk limbah B3 atau non B3. Peraturan yang sering dijadikan dasar dalam pelaksanaan pemanfaatan limbah industri adalah Peraturan Menteri Negara Lingkungan Hidup No.02 tahun 2008 tentang "Pemanfaatan imbah Bahan Berbahaya dan Beracun". Pada pasal 2, 3 dan 11 menjelaskan bahwa pemanfaatan limbah B3 dapat dilakukan dengan cara reuse, recycle dan recovery dengan mengutamakan perlindungan terhadap kesehatan dan keselamatan manusia serta perlindungan kelestarian lingkungan hidup dengan menerapkan prinsip kehati-hatian (Henggar, dkk, 2009).

Limbah padat yang berasal dari unit Instalasi Pengolahan Air Limbah (IPAL) proses fisika kimia terdiri dari $60 \%$ bahan organik berserat dan sisanya berupa bahan anorganik (pengisi atau filler). Dengan kandungan serat yang masih cukup tinggi, limbah tersebut dapat diolah kembali menjadi produk yang bernilai tambah, yang antara lain untuk pembuatan karton dan bahkan menjadi bahan bangunan misalnya batako. Kajian potensi dan kelayakan pemanfaatan limbah padat selain akan memberi nilai tambah bagi industri dan masyarakat sekitarnya juga menciptakan lingkungan yang bersih dan sehat.

Sejalan dengan kebutuhan pokok manusia tentang penyediaan rumah yang murah dan layak huni dan dalam mendukung program pemerintah perlu mengembangkan batako sistem interlok. Keuntungan penggunaan batako sistem interlok diantaranya adalah lebih cepat pengerjaan sehingga lebih ekonomis karena tidak menggunakan adukan spesi (mortar) sebagai perekat, selain itu hasil pemasangan lebih rapi, penggunaan acian lebih sedikit serta lebih tahan gempa. Namun demikian, batako sistem interlok yang berukuran standar masih perlu ditingkatkan dan dikembangkan misalnya dengan merekayasa komposisi dan susunan bahannya serta sistem pengunci saat digunakan sebagai partisi/dinding. Dengan berbagai kelebihannya maka produk batako interlok yang ringan mempunyai prospek yang bagus untuk digunakan di masyarakat.

Penelitian sebelumnya menyebutkan limbah sludge IPAL industri kertas sigaret memiliki karakteristik yang relatif tidak membahayakan lingkungan ditinjau atas dasar uji on waste, TCLP dan LD 50. Berdasarkan hasil uji potensi menunjukkan limbah tersebut dapat dimanfaatkan sebagai campuran pembuatan bata beton terutama dari kandungan $\mathrm{CaCO}_{3}$ maupun $\mathrm{CaO}$ (Henggar, dkk, 2009). Penelitian lain menyebutkan bahwa limbah sludge IPAL industri kertas berbahan baku waste paper dengan proses deinking dapat menghasilkan batako kualitas I dan II dengan komposisi tertentu (Dikdik, 2008).

Tulisan ini melaporkan hasil penelitian pemanfaatan sludge deinking yang cukup prospektif untuk dikembangkan karena dapat menghasilkan suatu produk baru sebagai bahan bangunan sehingga permasalahan penyediaan rumah murah layak huni dan penanganan limbah lumpur sebagai pengelolaan lingkungan dapat secara berkala teratasi.

\section{Limbah Sludge IPAL}

Limbah padat yang dihasilkan dari IPAL berupa lumpur (sludge) dengan kandungan bahan organik serat dan bahan anorganik lain. Jumlah dan karakteristik lumpur IPAL akan sangat dipengaruhi oleh karakteristik air limbahnya dan sistem pengolahannya, yaitu proses fisika, kimia atau biologi. Lumpur yang dihasilkan dari proses fisika atau fisika-kimia masih cukup banyak mengandung bahan organik berserat, sedangkan lumpur dari proses biologi banyak mengandung bahan organik sebagai biomassa mikroorganisme bukan lagi dalam bentuk serat.

Limbah padat yang dihasilkan industri kertas berasal dari beberapa unit proses yang umumnya berasal dari proses penyaringan bubur pulp (reject 
screen) dan proses pengolahan air limbah (IPAL). Namun yang sering menimbulkan masalah adalah yang berasal dari pengolahan air limbah berupa lumpur (sludge) yang jumlahnya cukup besar, yaitu berkisar antara 3-4\% per ton produk. Khusus untuk sludge deinking dari industri kertas menurut Peraturan Pemerintah No 85 tahun 1999 (Daftar Limbah B3 dari Sumber yang Spesifik), sludge deinking termasuk dalam kategori limbah B3 sehingga memerlukan penanganan yang cermat, efektif dan hati-hati. Kandungan logam berat yang terdapat pada sludge deinking berasal dari tinta atau pewarna yang bersifat toksik. Ketika zat toksik ini terpisah dari serat, maka menjadi bagian dari sludge yang termasuk limbah B3 yang harus ditangani secara cermat agar tidak menjadi masalah ketika dibuang di lingkungan. Namun demikian, berdasarkan Peraturan Menteri Lingkungan Hidup No. 02 tahun 2008 tentang Pemanfaatan Limbah Bahan Berbahaya dan Beracun, limbah ini dapat dimanfaatkan kembali menjadi beberapa jenis produk, salah satunya adalah bahan bangunan.

Limbah padat dari IPAL proses fisika-kimia sebagian besar (60\%) masih mengandung serat pendek dan sisanya berupa bahan pengisi dan bahan lainya. Kandungan air dalam limbah lumpur setelah dipekatkan dan dikeluarkan dari belt press mencapai kadar padatan kering sekitar 20-30\% (Syamsudin, 2007). Limbah padat ini jika dibuang langsung dengan cara ditimbun dalam areal terbuka (open dumping) akan menyebabkan masalah lingkungan, baik dari segi estetika maupun gangguan terhadap kesehatan serta pencemaran tanah dan air tanah. Sehingga ini menjadi permasalahan berat bagi industri dalam upaya pengelolaannya.

\section{Batako}

Batako adalah salah satu bahan bangunan dengan bahan pembentuk berupa pasir dan agregat (campuran pasir, kerikil dan air). Batako dicetak melalui proses pemadatan menjadi bentuk balokbalok dengan ukuran dan persyaratan tertentu dan proses pengerasannya ditempatkan pada tempat yang lembab atau tidak terkena sinar matahari langsung atau hujan. Batako dibedakan menjadi :

1. Bata Beton Pejal

Bata beton pejal adalah bata yang memiliki luas penampang pejal $75 \%$ atau lebih dari luas penampang seluruhnya dan memiliki volume pejal lebih dari $75 \%$ volume bata seluruhnya.

\section{Bata Beton Berlobang}

Bata beton berlobang adalah bata yang memiliki luas penampang lubang lebih dari $25 \%$ luas penampang batanya dan memiliki volume lubang lebih dari $25 \%$ volume bata seluruhnya.

3. Bata Beton Interlok

Bata beton interlok adalah bata yang dalam pembuatan dinding tidak membutuhkan adukan sebagai perekat antar bata, namun menggunakan tonjolan \& lekukan sehingga pada waktu dipasang akan saling mengunci baik diarah bidang dinding maupun tegak lurus bidang dinding.

Persyaratan utama yang harus dipenuhi oleh produk batako adalah kuat tekan, yaitu kekuatan yang dihasilkan dari pengujian tekan oleh mesin uji tekan yang merupakan beban tekan keseluruhan pada waktu benda uji pecah dibagi dengan ukuran luas nominal batako atau besarnya beban persatuan luas. Persyaratan ini yang menentukan tingkat mutunya, seperti yang diperlihatkan pada Tabel 1, yaitu klasifikasi bata beton pejal dan berlobang menurut SNI-03-0348-1989.

\section{BAHAN DAN METODE}

\section{Bahan}

Bahan percobaan yang digunakan dalam penelitian ini adalah :

- Limbah sludge primer berasal dari Instalasi Pengolahan Air Limbah (IPAL) industri kertas yang menggunakan bahan baku kertas bekas dan menggunakan proses deinking dalam produksinya

- Semen portland tipe I

- Pasir (agregat halus)

\section{Peralatan}

Peralatan yang digunakan meliputi :

- Alat cetak dan press

- Cetakan 5x5x5 cm

- Alat uji kuat tekan

- Perangkat lunak Solidworks ${ }^{\circledR} 2009$

\section{Metode Penelitian}

Metode penelitian terdiri dari tahapan kegiatan yaitu :

- Karakterisasi limbah sludge, mencakup kandungan organik, $\mathrm{CaCO}_{3}$, seratdanmorfologi 
Tabel 1. Klasifikasi Bata Beton menurut SNI-03-0348-1989

\begin{tabular}{|c|c|c|c|c|c|c|c|c|c|c|}
\hline \multirow{3}{*}{ No. } & \multirow{3}{*}{ Syarat Fisik } & \multirow{3}{*}{ Satuan } & \multicolumn{8}{|c|}{ Tingkat Mutu Bata } \\
\hline & & & \multicolumn{4}{|c|}{ Bata Pejal } & \multicolumn{4}{|c|}{ Bata Berlobang } \\
\hline & & & I & II & III & IV & $\mathrm{I}$ & II & III & IV \\
\hline 1 & Kuat tekan rata-rata minimum & $\mathrm{kg} / \mathrm{cm}^{2}$ & 100 & 79 & 40 & 25 & 70 & 50 & 35 & 20 \\
\hline 2 & $\begin{array}{l}\text { Kuat tekan bruto }{ }^{1} \\
\text { benda uji minimum }\end{array}$ & $\mathrm{kg} / \mathrm{cm}^{2}$ & 90 & 65 & 35 & 21 & 65 & 45 & 30 & 17 \\
\hline 3 & $\begin{array}{l}\text { Penyerapan air rata-rata } \\
\text { maksimum }\end{array}$ & $\%$ & 25 & 35 & & & 25 & 35 & & \\
\hline
\end{tabular}

Catatan:

1. Kuat tekan bruto adalah beban tekan keseluruhan pada waktu benda uji pecah dibagi dengan luas ukuran nyata dari permukaan bata yang tertekan, termasuk luas lobang serta cekungan tepi

2. Tingkat Mutu :

Tingkat I : untuk dinding non structural terlindungi

Tingkat II : untuk dinding structural terlindungi (boleh ada beban)

Tingkat III : untuk dinding non structural tak terlindungi boleh terkena hujan \& panas

Tingkat IV : untuk dinding non struktural terlindungi dari cuaca

- Pembuatan batako, meliputi :

- Penentuan campuran/komposisi antara PC dengan agregat (campuran pasir dan sludge)

- Pencetakan, disesuikan dengan persyaratan SNI

- Pengujian kualitas produk batako dengan uji kuat tekan sesuai standar uji

- Perancangan simulasi untuk penentuan bentuk batako interlock sebagai struktur self locking wall

\section{HASIL DAN PEMBAHASAN}

\section{Karakterisasi Limbah Sludge}

Hasil analisa komposisi limbah sludge IPAL menunjukkan bahwa sebagian besar komponen limbah sludge adalah $\mathrm{CaCO}_{3}$ (kapur) dan serat dengan komposisi seperti terlihat pada Tabel 2.

Berdasarkan data hasil uji kimia ternyata limbah sludge yang dihasilkan cukup baik sebagai agregat untuk bahan baku batako (bata beton). Hal ini terlihat pada kandungan senyawa $\mathrm{CaCO}_{3}$ yang cukup tinggi yaitu lebih dari $60 \%$, sehingga kemungkinan dalam pembuatan produk batako tidak akan banyak mengalami penyusutan (Henggar, 2009). Selain itu, jumlah serat yang terkandung dalam sludge akan menyebabkan pasir lebih banyak mengisi rongga-rongga sehingga batako akan lebih padat, yang pada akhirnya akan meningkatkan kekuatan tekan produk.
Tabel 2. Hasil Analisis Komposisi Limbah Sludge

\begin{tabular}{|c|c|c|c|}
\hline No. & Parameter & Satuan & $\begin{array}{l}\text { Limbah } \\
\text { Sludge } \\
\text { IPAL }\end{array}$ \\
\hline 1 & $\begin{array}{l}\text { Senyawa } \\
\text { Organik }\end{array}$ & $\%$ & 34,51 \\
\hline 2 & Total Selulosa & $\%$ & 9,18 \\
\hline 3 & $\mathrm{CaO}$ & $\%$ & 50,51 \\
\hline 4 & $\mathrm{CaCO}_{3}$ & $\%$ & 65,49 \\
\hline 5 & Diameter Serat & $\mathrm{mm}$ & 40,05 \\
\hline 6 & Jumlah Serat & & 1270 \\
\hline
\end{tabular}

\section{Perlakuan Campuran/Komposisi}

Keuntungan yang didapat dengan penggunaan limbah sludge dalam jumlah besar untuk pembuatan batako adalah nilai ekonomi yang diperoleh sebagai produk samping. Secara umum harga agregat lebih murah dari pada semen, sehingga penggunaannya selalu diusahakan lebih banyak tanpa mengurangi kualitas produk. Pembuatan batako dilakukan dengan berbagai variasi komposisi campuran PC dan agregat yaitu dengan variasi $1: 6$ dan 1 : 8 , sedangkan agregat yang merupakan campuran pasir dan sludge divariasikan pada komposisi $70 \%, 50 \%, 30 \%$ dan $0 \%$ limbah sludge. Hasil uji kuat tekan dari produk batako dengan masa curing selama 28 hari seperti diperlihatkan pada Tabel 3. 


\section{Pencetakan}

Pencetakan dilakukan terhadap semua perlakuan komposisi untuk mendapatkan ukuran benda uji yang dipersyaratkan dalam SNI 030349-1989, yaitu $5 \mathrm{~cm}$ x $5 \mathrm{~cm} \times 5 \mathrm{~cm}$.

\section{Pengujian Kualitas}

Secara keseluruhan produk batako yang dihasilkan menunjukan kecenderungan kuat tekan benda uji menurun seiring dengan meningkatnya persentase limbah sludge, seperti terlihat pada Gambar 1.

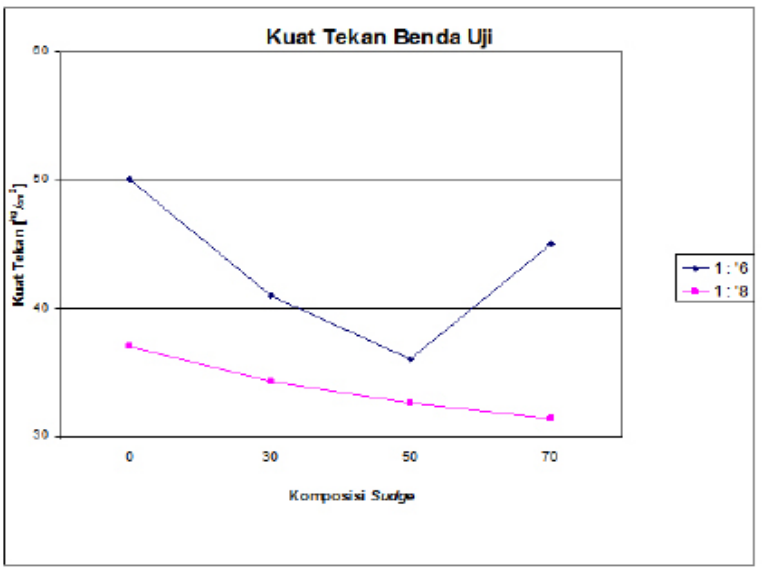

Gambar 1. Kuat Tekan Benda Uji

Pada Gambar 1, terlihat adanya penyimpangan data yaitu pada komposisi 1: 6 dengan $70 \%$ sludge (3-6). Sehingga korelasi antara penambahan sludge dengan penurunan kuat tekan tidak terbukti, ini dapat disebabkan oleh banyak faktor, salah satunya adalah pada saat proses pencetakan benda uji. Untuk mengatasi ini, maka harus dibuat persamaan regresi dari data yang dihasilkan, sehingga penyimpangan data dapat diabaikan, seperti yang diperlihatkan pada Gambar 2 dan Gambar 3.

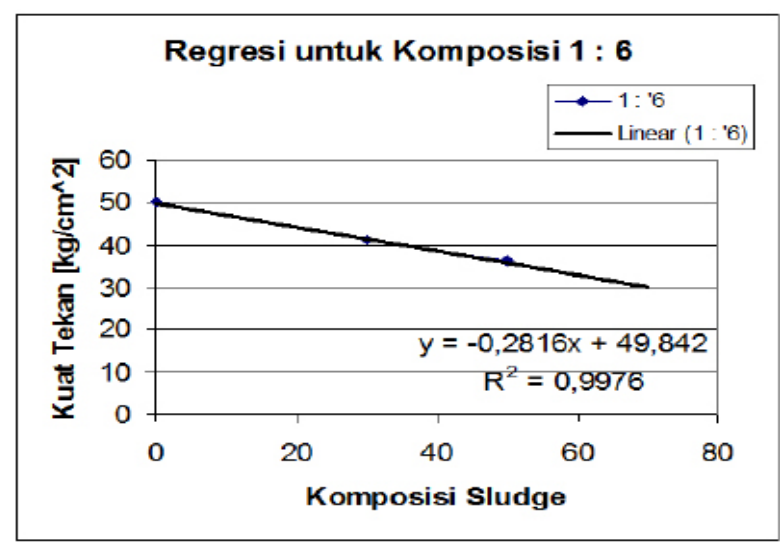

Gambar 2. Pendekatan Regresi untuk Komposisi $1: 6$

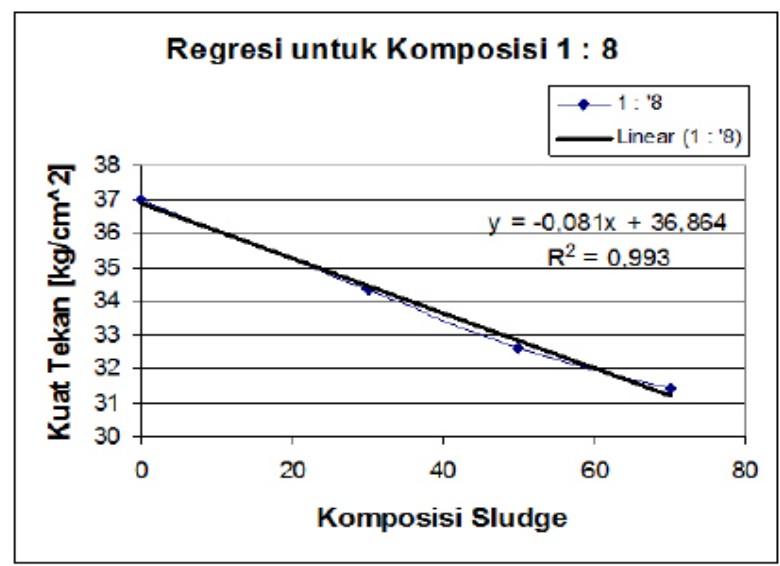

Gambar 3. Pendekatan Regresi untuk Komposisi $1: 8$

Tabel 3. Hasil Uji Kuat Tekan Benda Uji

\begin{tabular}{cccccc}
\hline \multirow{2}{*}{ No. } & \multirow{2}{*}{ Kode } & $\begin{array}{c}\text { Komposisi } \\
\text { PC : Agregat }\end{array}$ & $\begin{array}{c}\text { Komposisi Sludge } \\
\%\end{array}$ & \multicolumn{2}{c}{ Kuat Tekan } \\
\cline { 5 - 6 } & & & 0 & $\mathrm{~kg} / \mathrm{cm}^{2}$ & $\mathrm{~N} / \mathrm{m}^{2}$ \\
\hline 1 & St - & & 30 & 50 & 5.000 .000 \\
2 & A1 - & $1: 6$ & 50 & 41 & 4.100 .000 \\
3 & A2 - 6 & & 70 & 36 & 3.600 .000 \\
4 & A3 - & & 0 & 45 & 4.500 .000 \\
5 & St - 8 & & 30 & 37 & 3.700 .000 \\
6 & A1 - 8 & \multirow{2}{*}{$1: 8$} & 50 & 34,3 & 3.430 .000 \\
7 & A2 - & & 70 & 32,6 & 3.260 .000 \\
8 & A3 - 8 & & & 31,4 & 3.140 .000 \\
\hline
\end{tabular}


Hasil yang didapat dari persamaan regresi diatas diperlihatkan pada Tabel 4. Dari hasil regresi tersebut diatas, dapat disimpulkan bahwa penambahan sludge menyebabkan penurunan kuat tekan dari produk. Namun demikian, untuk penambahan jumlah sludge terbanyak sebesar $70 \%$ masih memberikan hasil yang cukup baik, karena masih berada pada Kelas IV, yaitu diatas $21 \mathrm{~kg} / \mathrm{cm}^{2}$.

\section{Perancangan Simulasi}

Hal pertama yang harus dilakukan dalam perancangan produk adalah menentukan parameter kunci untuk dimensi produk, yaitu berdasarkan dimensi panel kolom rumah knock down, yang dapat dilihat pada Gambar 4.

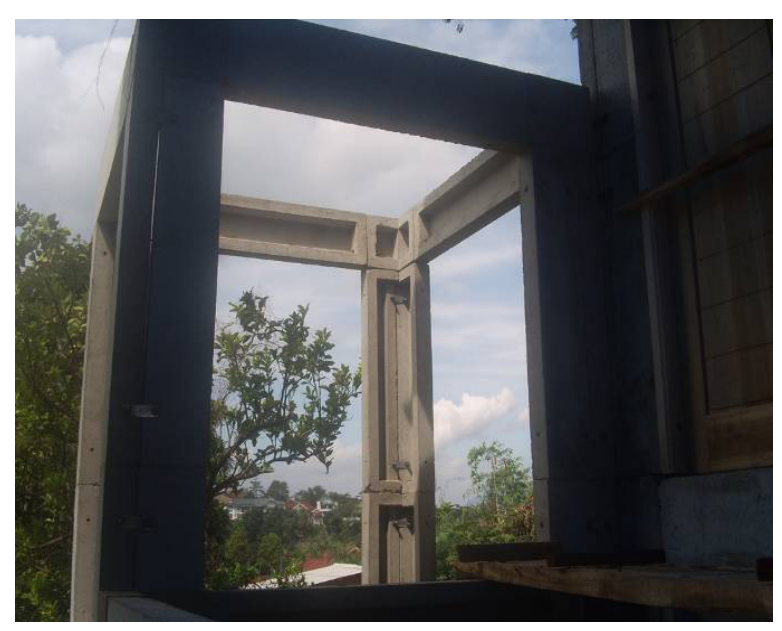

Gambar 4. Gambar Panel Kolom

Komponen yang membentuk struktur rumah knock-down ini adalah 3 jenis panel yang disambung dengan baut-baut, yaitu :
- $\quad$ panel struktur STR $1(48,5 \mathrm{~kg})=10 \mathrm{~cm}$ x 30 $\mathrm{cm} \times 120 \mathrm{~cm}$

- $\quad$ panel struktur STR $2(35 \mathrm{~kg})=10 \mathrm{~cm} \times 20$ $\mathrm{cm}$ x $120 \mathrm{~cm}$

- panel simpul/pengikat berbentuk L $(30 \mathrm{~kg})=$ $10 \mathrm{~cm} \times 30 \mathrm{~cm} \times 30 \mathrm{~cm}$

Dimensi ketebalan menjadi langkah awal untuk menentukan dimensi lainnya (panjang dan tinggi), sedangkan ntuk menentukan panjang dan tinggi, digunakan SNI 03-0349-1989 sebagai acuan, yaitu

1. Panjang $=393 \mathrm{~mm}$ (maksimal)

2. Lebar $=102 \mathrm{~mm}$ (maksimal)

Ditetapkan pula luas permukaan pengisi (dinding) yaitu sebesar 2,4 $\mathrm{m} \times 2,4 \mathrm{~m}$. Dari pertimbangan parameter kunci tersebut, maka ditetapkan bentuk dan dimensi produk seperti diperlihatkan pada Gambar 5.

Untuk mendapatkan bentuk pengunci yang optimal, maka dilakukan simulasi untuk melihat distribusi tegangan pada masing-masing bentuk pengunci, hasil simulasi dapat dilihat pada Gambar 6. Secara visual dapat diambil kesimpulan bahwa distribusi tegangan terkecil adalah pada pengunci dengan bentuk trapesium, sehingga bentuk pengunci ini dipilih dalam analisa bentuk batako sebagai struktur self-locking wall.

Dari bentuk yang telah ditetapkan, dilakukan simulasi terhadap kekuatan produk untuk memberikan gambaran pada saat penerapan di lapangan. Simulasi menggunakan perangkat lunak Solidworks ${ }^{\circledR} 2009$, dengan pendekatan properties yang dimiliki oleh program tersebut yaitu material concrete, seperti yang diperlihatkan pada Tabel 5.

Tabel 4. Perbandingan Kuat Tekan Benda Uji

\begin{tabular}{|c|c|c|c|c|c|}
\hline \multirow{2}{*}{ No. } & \multirow{2}{*}{ Kode } & \multirow{2}{*}{$\begin{array}{c}\text { Komposisi } \\
\text { PC : Agregat }\end{array}$} & \multirow{2}{*}{$\begin{array}{c}\text { Komposisi Sludge } \\
\%\end{array}$} & \multicolumn{2}{|c|}{ Kuat Tekan } \\
\hline & & & & $\mathrm{kg} / \mathrm{cm}^{2}$ & $\mathrm{~N} / \mathrm{m}^{2}$ \\
\hline 1 & St - 6 & \multirow{4}{*}{$1: 6$} & 0 & 50 & 5.000 .000 \\
\hline 2 & A1 -6 & & 30 & 41 & 4.100 .000 \\
\hline 3 & A2 - 6 & & 50 & 36 & 3.600 .000 \\
\hline 4 & A3 -6 & & 70 & 45 & 4.500 .000 \\
\hline 5 & St -8 & \multirow{4}{*}{$1: 8$} & 0 & 37 & 3.700 .000 \\
\hline 6 & A $1-8$ & & 30 & 34,3 & 3.430 .000 \\
\hline 7 & A2 -8 & & 50 & 32,6 & 3.260 .000 \\
\hline 8 & A3 -8 & & 70 & 31,4 & 3.140 .000 \\
\hline
\end{tabular}




\begin{tabular}{lllll}
\hline \multicolumn{2}{c}{ Tipe 1 } & \multicolumn{2}{c}{ Tipe 2 } & Tipe 3 \\
\hline & & & & \\
& & & & \\
& & & & \\
\hline
\end{tabular}

Gambar 5. Bentuk Self-locking Wall

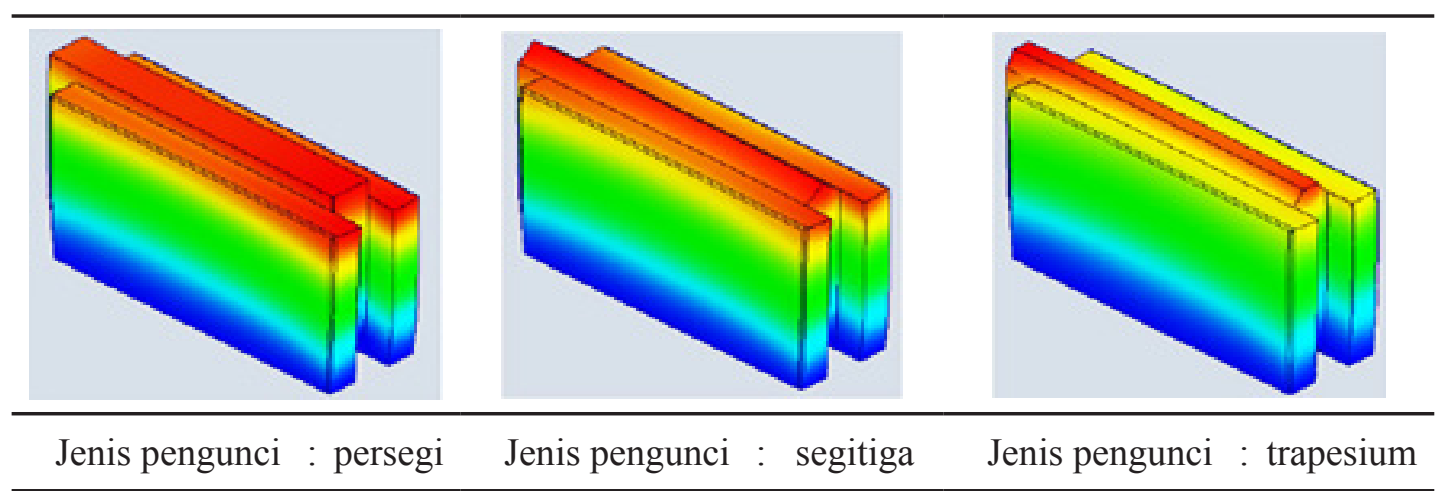

Gambar 6. Hasil Simulasi Distribusi Tegangan

Tabel 5. Properties of Self-locking Wall dari Solidworks ${ }^{\circledR} 2009$

\begin{tabular}{|c|c|c|c|}
\hline No. & Parameter & Satuan & Besaran \\
\hline 1 & Elastic Modulus & $\mathrm{N} / \mathrm{mm}^{2}$ & 220590 \\
\hline 2 & Poisson Ratio & & 0,2 \\
\hline 3 & Shear Modulus & $\mathrm{N} / \mathrm{mm}^{2}$ & 90407 \\
\hline 4 & Density & $\mathrm{gr} / \mathrm{cm}^{3}$ & $1,02-1,81$ \\
\hline 5 & $\begin{array}{l}\text { Thermal } \\
\text { Conductivity }\end{array}$ & $\mathrm{W} / \mathrm{m} . \mathrm{K}$ & 1,7 \\
\hline 6 & Specific Heat & $\mathrm{J} / \mathrm{kg} \cdot \mathrm{K}$ & 878 \\
\hline 7 & Tensile Strength & $\mathrm{N} / \mathrm{mm}^{2}$ & 172,34 \\
\hline 8 & $\begin{array}{l}\text { Thermal Expansion } \\
\text { Coefficient }\end{array}$ & $/ \mathrm{K}$ & $1,08 \mathrm{E}-5$ \\
\hline 9 & $\begin{array}{l}\text { Compressive } \\
\text { Strength }\end{array}$ & $\mathrm{N} / \mathrm{mm}^{2}$ & $22,35-42,36$ \\
\hline
\end{tabular}

Ditetapkan pula, komposisi yang akan disimulasikan, yaitu komposisi yang menyerap sludge diatas $50 \%$. Untuk mengisi dinding $(2,4 \mathrm{~m}$ x 2,4 m) dengan menggunakan self-locking wall, maka dibutuhkan 70 buah batako, yaitu 10 buah susunan arah vertikal dan 7 buah susunan arah horizontal, seperti diperlihatkan pada Gambar 7. Dengan bobot tiap produk berkisar antara 3-6 kg, didapatkan data seperti yang diperlihatkan pada Tabel 6.

Tabel 6. Data Hasil Simulasi Self-locking Wall

\begin{tabular}{cccccc}
\hline \multirow{2}{*}{ Kode } & Volume & Massa & $\mathrm{F}$ & \multicolumn{2}{c}{ Stress Analysis } \\
\cline { 2 - 6 } & $\mathrm{cm}^{3}$ & gr & $\mathrm{N}$ & $\left(\mathrm{N} / \mathrm{m}^{2}\right)$ & $\mathrm{Kg} / \mathrm{cm}^{2}$ \\
\hline A2-6 & 7190,12 & 5716,145 & 514 & 80.365 & 80 \\
$\mathrm{~A} 3-6$ & 7190,12 & 6507,059 & 586 & 91.622 & 92 \\
$\mathrm{~A} 2-8$ & 7190,12 & 5033,084 & 201 & 31.427 & 31 \\
$\mathrm{~A} 3-8$ & 7190,12 & 4170,269 & 167 & 26.111 & 26 \\
\hline
\end{tabular}



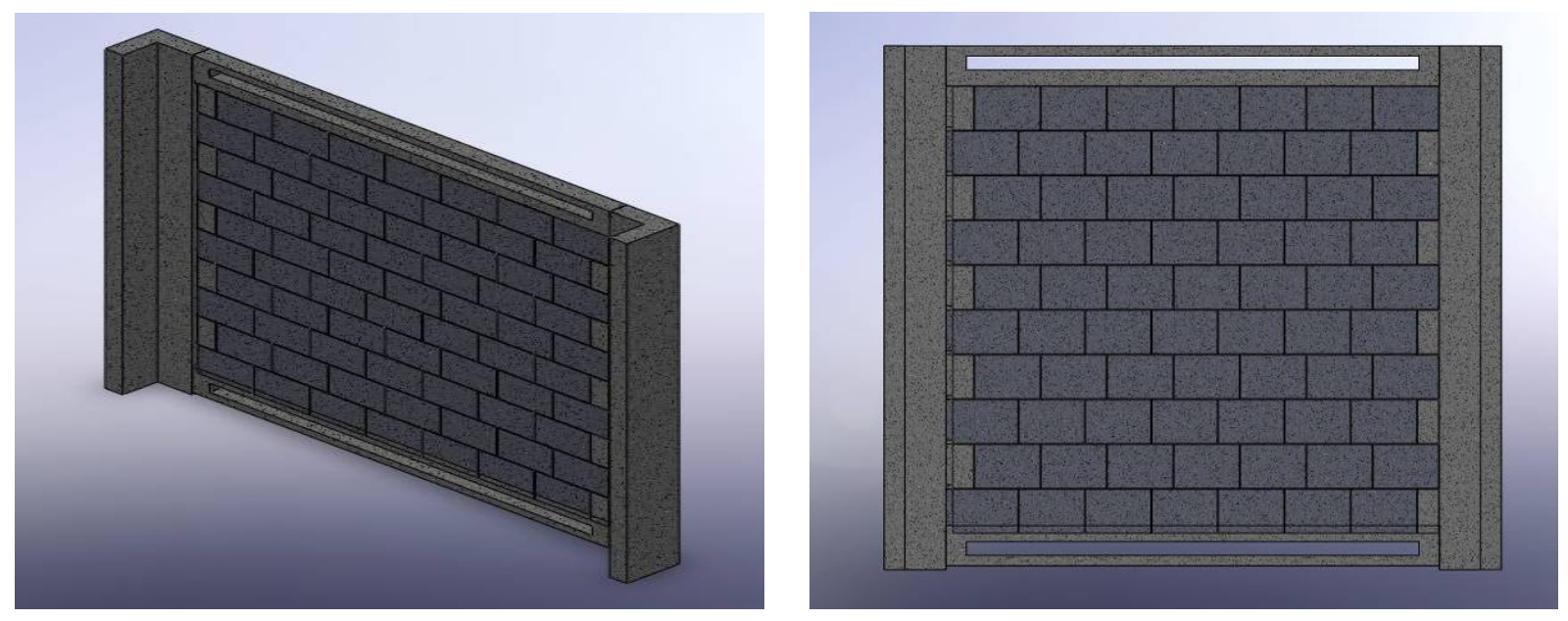

Gambar 7. Struktur Dinding Self-locking Wall

Untuk menentukan keamanan konstruksi yang digunakan, maka harus dianalisa dengan menggunakan Factor of Safety (FOS), seperti yang diperlihatkan pada Tabel 7 .

Tabel 7. Factor of Safety

\begin{tabular}{ccccc}
\hline & & \multicolumn{2}{c}{ Kuat Tekan $\left[\mathrm{kg} / \mathrm{cm}^{2}\right]$} & \\
\cline { 3 - 4 } No. & Kode & Hasil Uji & $\begin{array}{c}\text { Hasil } \\
\text { Simulasi }\end{array}$ & \\
\hline 1 & A2 -6 & 35,76 & 80 & 0,447 \\
2 & A3 -6 & 30,13 & 92 & 0,3275 \\
3 & A2 -8 & 32,81 & 31 & 1,058387 \\
4 & A3 -8 & 31,19 & 26 & 1,199615 \\
\hline
\end{tabular}

\section{KESIMPULAN}

1. Hasil pengujian kuat tekan dan hasil regresi dari tiap komposisi menunjukan bahwa penambahan sludge dalam campuran agregat dapat menyebabkan penurunan kuat tekan produk batako. Pada penambahan sludge sampai $70 \%$ masih menghasilkan produk batako kualitas mutu kelas IV dengan kuat tekan lebih dari $21 \mathrm{~kg} / \mathrm{cm}^{2}$.

2. Sludge yang dapat digunakan untuk konstruksi yang dirancang adalah kode pengujian 2-8 dengan nilai FOS 1,058387 dan kode pengujian 3-8 dengan nilai FOS 1,199615. Sludge tersebut berasal dari pabrik kertas industri, dengan bahan baku deinked pulp dan kertas bekas (kode A), komposisi (semen : agregat) 1: 8, dengan persentase serat sebanyak $50 \%$ dan $70 \%$.
3. Dimensi Batako untuk Self-locking Wall, adalah :

- Panjang $=35,3 \mathrm{~cm}$

- Lebar $=9,5 \mathrm{~cm}$

- Tinggi $=24,3 \mathrm{~cm}$

- Pengunci $=$ trapesium

\section{SARAN}

Untuk penelitian selanjutnya, penulis menyarankan beberapa hal, sebagai berikut :

1. Melakukan perancangan pengunci atau penyambung antara struktur self-locking wall dengan kolom rumah knock-down.

2. Mengkaji pengaruh komponen penunjang atau bahan penolong lain terhadap kuat tekan produk bila digunakan untuk memperbaiki tampilan permukaan produk

\section{DAFTAR PUSTAKA}

Didik Bambang Supriyadi, 2008. Pemanfaatan Limbah Padat (Sludge) Pabrik Kertas Sebagai Bata Beton (Batako) Untuk Mereduksi Kuantitas Limbah, Laporan Penelitian ITS

Henggar Hardiani, Susi S, 2009. Pemanfaatan Limbah Sludge Industri Kertas Sigaret untuk Bahan Baku Bata Beton, Berita Selulosa, Vol. 44 No. 2, Hal. 86-98

John Newman, Ban Seng Choo, 2003. Advanced Concrete Technology, Concrete Properties, Elsevier Ltd

Kuntari Adi Suhardjo, Ariyadi Basuki, 2009. Alternatif Pemanfaatan Perlite sebagai Produk Bata Beton Ringan, Laporan Penelitian B4T 
Peraturan Pemerintah No 85 tahun 1999 tentang Limbah B3 dari Sumber yang Spesifik

Peraturan Menteri Lingkungan Hidup No. 02 tahun 2008 tentang Pemanfaatan Limbah Bahan Berbahaya dan Beracun

Portland Cement Association, 2002. Design and Control of Concrete Mixture, 14th Edition

Syamsudin, Sri Purwati, Ike Rostika, 2007. Pemanfaatan Campuran Limbah Padat Dengan Lindi Hitam Dari Industri Pulp Dan Kertas Sebagai Bahan Biobriket, Berita Selulosa, Vol. 42, No. 2, 68 - 75
Wattimena, Reza Bastari Imran, 2007. Pemanfaatan Limbah Padat Berserat dari Instalasi Pengolahan Air Limbah Pabrik Kertas untuk Produk Karton \& Papan Semen, Laporan RUT BBPK 